\title{
NO RELATIONSHIP BETWEEN FECUNDITY AND ANNUAL REPRODUCTIVE RATE IN BONY FISH
}

\author{
Rainer FROESE ${ }^{1 *}$, Susan $L U N A^{2}$ \\ ${ }^{1}$ Leibniz Institute of Marine Sciences, Kiel, Germany \\ ${ }^{2}$ WorldFish Center, Makati, Philippines
}

Froese R., Luna S., 2004. No relationship between fecundity and annual reproductive rate in bony fish. Acta Ichthyol. Piscat. 34 (1): 11-20.

Background. There is still a widespread notion that bony fishes with high fecundities are more productive and therefore more resistant to overexploitation. The purpose of this study was to formally explore the relationship between fecundity and reproductive success expressed as maximum annual reproductive rate, i.e. the number of new spawners produced by existing spawners at low population densities.

Material and methods. We used maximum annual reproductive rate from a recent study covering 49 species of bony fish; we used fecundity estimates from the published literature.

Results. We found no significant relationship between fecundity (ranging from 368 to 10 million eggs) and maximum annual reproductive rate (ranging from 0.4 to 13.5 replacement spawners).

Conclusion. Fecundity in oviparous bony fish without parental care has no relation with reproductive success. Apparently high fecundity in bony fish has evolved to counterbalance pre-adult mortality, as indicated by the fact that variance in fecundity is 3 orders of magnitude larger than variance in annual reproductive rate.

Key words: fish, fecundity, annual reproductive rate, pre-adult mortality.

\section{INTRODUCTION}

The widespread notion that the high fecundity of fish protects them against overexploitation is rather old, and can be traced at least to Jean-Baptiste de Monet de Lamarck, who thought that: "animals living in the waters, especially the sea waters are protected from the destruction of their species by man. Their multiplication is so rapid and their means of evading pursuit or traps are so great that there is no likelihood of his being able to destroy the entire species of these animals" (Lamarck 1809). The 'rapid multiplication' mentioned here was probably inferred from the well-known high fecundity of most commercial fish. However, if such relationship existed then the

\footnotetext{
* Correspondence: Dr Rainer Froese, Leibniz Institute of Marine Sciences, Düsternbrooker Weg 20, 24105 Kiel, Germany, e-mail: rfroese@ifm-geomar.de
} 
oceans of the world should be packed with ocean sunfish, Mola mola (Linnaeus, 1758), which made it into the Guinness Book of World Records (Foot 2000) as the most fecund fish with up to 300 million eggs per female. In reality, however, the ocean sunfish is less abundant than some sharks with very low fecundity. Indeed, this paradox was noted by Charles Darwin, who observed that: "[t]he picked dog-fish (Squalus acanthias) actually swarms on many coasts \& yet is said to lay only six *eggs; whereas the cod-fish sometimes lays above three million \& a half" (Stauffer 1975). Similarly, Hjort (1914) at the dawn of fishery research observed that: “... it is difficult to avoid the conclusion that the actual quantity of eggs spawned is not a factor in itself sufficient to determine the numerical value of a [resulting] year class."

The reproductive rate of animals is defined as the average number of offspring per parent that survive to a certain age. If such age is taken as age at first maturity, then we obtain the number of replacement spawners per spawner. Population theory suggests that this rate will be near its maximum at low population densities far from the carrying capacity of the respective ecosystem (Baranov 1918, Ricker 1975, Myers and Mertz 1997, Myers 2001). Myers et al. (1999) provided estimates of maximum annual reproductive rate at low population densities for 57 species of bony fish based on analyses of spawner-recruitment series for 700 stocks. They reviewed various methods that have been used to estimate reproductive rate in fishes and concluded that the standardized slope at the origin of the spawner-recruitment function was most appropriate, being relatively constant within species and with relatively little variance among species. Here we use these data to explore the relationship between annual reproductive rate and annual mean and minimum fecundity.

\section{MATERIAL AND METHODS}

Maximum annual reproductive rates $(\alpha)$ at low population densities were taken from Myers et al. (1999). For annual fecundity we used two independent data sets: The first set is from Mertz and Myers (1996) who provided "mean fecundity per year for reproductive individuals" for twenty-three species.

The second set consists of fecundity estimates from the literature as compiled in FishBase (Froese and Pauly 2000). For the purpose of this study we assumed that the lower end of fecundity ranges given in the literature was a reasonable proxy for fecundity at first maturity. No fecundity estimates were found for Pennahia argentata and Pleurogrammus monopterygius. Table 1 shows the maximum annual reproductive rates of Myers et al. (1999), mean fecundity estimates by Mertz and Myers (1996), and fecundity at first maturity estimates, together with the respective references. 
Table 1

Maximum annual reproductive rate $(\alpha)$, mean and minimum annual fecundity with references for 49 species used in this study

\begin{tabular}{|c|c|c|c|c|}
\hline Species & $\alpha^{*}$ & $\begin{array}{c}\text { Annual } \\
\text { Fecundity } \\
\text { (mean)** }\end{array}$ & $\begin{array}{c}\text { Annual } \\
\text { Fecundity } \\
\text { (min.) }\end{array}$ & References \\
\hline Alosa aestivalis & 13.5 & & 52300 & Jessop 1993 \\
\hline Alosa pseudoharengus & 3.63 & & 68400 & Jessop 1993 \\
\hline Alosa sapidissima & 5.21 & & 70000 & Melvin et al. 1985 \\
\hline Brevoortia patronus & 3.49 & 335000 & 5000 & Lewis and Roithmayr 1981 \\
\hline Brevoortia tyrannus & 9.02 & 335000 & 38000 & Higham and Nicholson 1964 \\
\hline Clupea harengus & 2.08 & 142000 & 20000 & Muus and Nielsen 1999 \\
\hline Engraulis encrasicolus & 2.01 & & 13000 & Muus and Nielsen 1999 \\
\hline Engraulis mordax & 1.39 & 25000 & 20000 & Hart 1973 \\
\hline Esox lucius & 1.66 & & 25000 & Koli 1990 \\
\hline Gadus morhua & 3.94 & 2000000 & 500000 & Muus and Nielsen 1999 \\
\hline Harpodon nehereus & 1.36 & & 89600 & Fernandez and Devaraj 1996 \\
\hline Lophius budegassa & 0.93 & & 46320 & Tsimenidis 1980 \\
\hline Lutjanus campechanus & 6.68 & & 11613 & Collins et al. 1996 \\
\hline Melanogrammus aeglefinus & 2.05 & 700000 & 55000 & Cohen et al. 1990 \\
\hline Merlangius merlangus & 3.13 & 400000 & 109358 & Christiansen et al. 1997 \\
\hline Merluccius bilinearis & 0.84 & 700000 & & \\
\hline Merluccius hubbsi & 3.25 & & 267400 & Ehrlich 1998 \\
\hline Merluccius productus & 0.39 & 79000 & 33000 & MacGregor 1966 \\
\hline Micromesistius poutassou & 1.8 & 200000 & 122000 & Christiansen et al. 1997 \\
\hline Morone saxatilis & 2.58 & & 14000 & Scott and Crossman 1973 \\
\hline Oncorhynchus gorbuscha & 3.39 & 1500 & 800 & Scott and Crossman 1973 \\
\hline Oncorhynchus keta & 3.71 & 3600 & 2400 & Scott and Crossman 1973 \\
\hline Oncorhynchus nerka & 4.81 & 3600 & 368 & Scott and Crossman 1973 \\
\hline Oncorhynchus tshawytscha & 7.32 & & 4242 & Scott and Crossman 1973 \\
\hline Pagrus auratus & 3.82 & & 150000 & Hayes 1994 \\
\hline Platichthys flesus & 0.97 & & 400000 & Spratte and Hartmann 1997 \\
\hline Limanda ferruginea & 2.2 & 1500000 & & \\
\hline Pleuronectes platessa & 2.51 & 80000 & 50000 & Muus and Nielsen 1999 \\
\hline Pollachius virens & 3.19 & 225000 & 220000 & Christiansen et al. 1997 \\
\hline Reinhardtius hippoglossoides & 2.12 & 165000 & 15000 & Junquera et al. 1999 \\
\hline Salmo salar & 4.31 & 8300 & 8000 & Muus and Dahlström 1974 \\
\hline Salvelinus fontinalis & 4.71 & & 1000 & Scott and Crossman 1973 \\
\hline Salvelinus namaycush & 2.51 & & 5000 & Spillman 1961 \\
\hline Sardina pilchardus & 0.57 & & 50000 & Muus and Nielsen 1999 \\
\hline Sardinops sagax & 1.93 & 200000 & 10000 & Fletcher 1990 \\
\hline Scomber japonicus & 0.95 & 1000000 & 101859 & Ciechomski and Capezzani 1969 \\
\hline Scomber scombrus & 3.03 & 400000 & 200000 & Muus and Nielsen 1999 \\
\hline Sebastes goodie & 0.43 & & 29000 & Hart 1973 \\
\hline Solea solea & 1.93 & 350000 & 100000 & Muus and Nielsen 1999 \\
\hline Sprattus sprattus & 2.39 & & 242800 & Torstensen 1985 \\
\hline Stenotomus chrysops & 13.5 & & 3860 & Gray 1990 \\
\hline Stizostedion vitreum & 2.48 & & 46524 & Sakamoto and White 1974 \\
\hline Theragra chalcogramma & 1.32 & 600000 & 60000 & Witherell 1996 \\
\hline Thunnus albacares & 4.18 & & 200000 & McPherson 1991 \\
\hline Thunnus obesus & 2.08 & & 2900000 & Collette and Nauen 1983 \\
\hline Thunnus thynnus & 0.67 & & 10000000 & Muus and Nielsen 1999 \\
\hline Trachurus mediterraneus & 1.28 & & 425061 & Anon. 2001 \\
\hline Trachurus trachurus & 1.68 & 364000 & 77090 & Deniel 1989 \\
\hline Xiphias gladius & 5.47 & & 2000000 & Nakamura 1985 \\
\hline
\end{tabular}

* Values taken from Myers et al. 1999, **Values taken from Mertz and Myers 1996. 


\section{RESULTS AND DISCUSSION}

Fecundity in number of eggs spawned annually per female is mainly a function of female body weight, and thus population fecundity depends foremost on the size composition of females in a given spawning stock. For the purpose of this study we considered two scenarios: 1) that spawning stocks at low densities consists mainly of first-time spawners (Ballara and Livingston 2001, Murphy and Crabtree 2001, Walsh et al. 2003) and therefore fecundity at age of first maturity is taken as proxy for population fecundity; and 2) that spawning stocks have some age structure and therefore mean fecundity is taken as proxy of population fecundity (Mertz and Myers 1996).

Myers et al. (1999) suggested that the maximum annual reproductive rate $(\alpha)$ is lognormally distributed, "usually ranging from 1 to 7 for species for which we have several populations in our analysis." We re-examined their data and found the annual reproductive rates of Anoplopoma fimbria $(\alpha=0.10)$, Coilia dussumieri $(\alpha=15.3)$, Plecoglossus altivellis $(\alpha=113)$, Sebastes alutus $(\alpha=0.15)$, Sebastes mentella ( $\alpha=0.34$ ), and Thunnus maccoyii $(\alpha=0.22)$ to be outliers (distance from mean much larger than two standard deviations) if log-normal distribution of $\alpha$ is assumed. After removal of these species the dataset passed normality tests (Skewness Test: Value $=-0.19$, $Z=-0.62$, Prob. $=0.5342$; Kurtosis Test: Value $=3.07, Z=0.52$, Prob. $=0.6002$; Omnibus Test: $K_{2}=0.66$, Prob. $=0.7186$ ).

Mertz and Myers (1996) found no significant relationship between recruitment variability and fecundity. In the present paper we explored the relationship between reproductive rate and fecundity. Fig. 1 shows a plot of maximum annual reproductive rates versus mean fecundity (solid dots) and minimum fecundity (open dots). Analysis of variance results in acceptance of the null hypothesis for minimum fecundity estimates $\left(F_{43,0.05}=1.99 ; P=0.266\right)$ as well as for mean fecundity $\left(F_{17,0.05}=2.91 ; P=0.121\right)$, i.e. there is no significant correlation between fecundity and reproductive success as expressed by the maximum annual reproductive rate. Myers and Barrowman (1996) and Myers (1997) demonstrated that especially at low population sizes "recruitment is a function of spawner abundance." Sadovy (2001) presents evidence of depensation, i.e. less than expected reproductive success at very low population densities. Combining these findings with our results suggests that the number of spawners is more important for recruitment than the number of eggs produced. We hypothesise that a high number of spawners will cover a larger area and a wider time window in sufficient densities and thus increase the chances that at least some batches of eggs and larvae encounter conditions in their highly variable aquatic environment that favour survival and growth. 


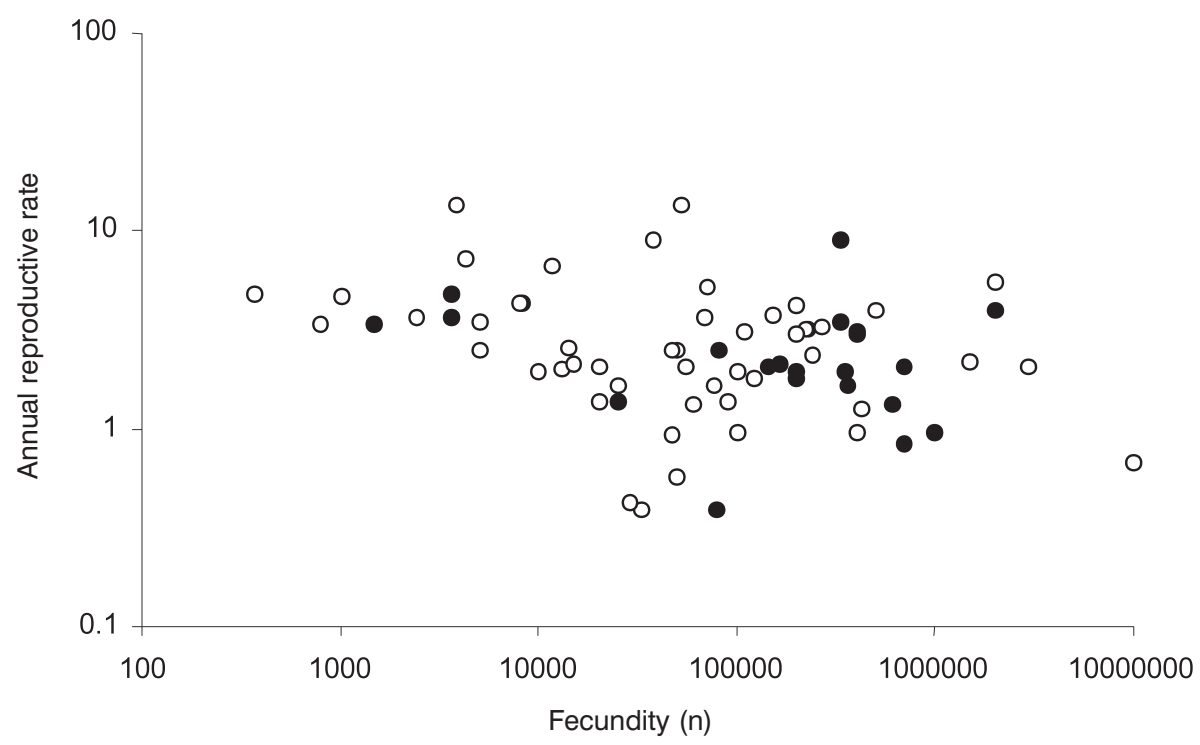

Fig. 1. Maximum annual reproductive rate versus mean (solid dots) and minimum (open dots) annual fecundity

Our results confirm a study by Denney et al. (2002) who found no relationship between annual reproductive rate (which they term 'adult production') and fecundity in 20 fish species of the Northeast Atlantic. They found a negative correlation between 'recruit production' and fecundity, but this may be biased by the artificial nature of the age at recruitment, i.e. the age when fish are first caught, compared to the age at first maturity. Our analysis of a larger data set confirms the conclusion of Denney et al. (2002) that there is no basis for assuming that high fecundity confers high resilience to exploitation; such misconceptions actually pose a threat to highly fecund fishes (Sadovy 2001). Note that our study refers strictly to highly fecund bony fish, not to species with very low fecundities such as most elasmobranchs which have annual reproductive rates an order of magnitude below bony fish (Smith et al. 1998) and thus appear unsuitable to withstand commercial fishing pressure.

Serge Garcia (FAO, pers. comm.) pointed out that an un-fished population reduced by natural events such as a sequence of recruitment failures will consist mostly of large, old fishes with higher fecundity, larger eggs and larvae, and more 'spawning experience', all of which should contribute to increased reproductive success per spawner in addition to density-related effects enhancing pre-adult survival. In contrast, a population reduced by fishing will consist mostly of first-time spawners with lower fecundity, less viable eggs and larvae, and no spawning experience (Longhurst 2002). Thus, the maximum annual reproductive rate can be expected to be different depending whether it was estimated from a population reduced by fishing or 
by natural events. We agree with this reasoning, which would suggest that the $\alpha$-estimates of Myers et al. (1999)—which were derived from heavily fished stocksshould be lower than those derived from populations reduced by natural events. Such bias should, however, have no bearing on the missing relationship between fecundity and maximum annual reproductive rate explored in this study.

The variance of the maximum annual reproductive rate $(\alpha)$ is considerably smaller than that of fecundity, which spans 5 orders of magnitude in oviparous bony fish without parental care (Fig. 1). Given that $\alpha$-which was derived here without consideration of fecundity - can be viewed as the product of annual fecundity $(F)$ and the fraction surviving to maturity $(S)$ and given that there is no relationship between $\alpha$ and $F$, it follows that there is also no relationship between $\alpha$ and pre-adult survival $(S)$. Thus, it seems that high fecundity has evolved primarily to counter-balance preadult mortality typically suffered by offspring, resulting on average in a maximum annual reproductive rate that is high enough to ensure replacement of spawners and population growth, and small enough to avoid over-investment in reproductive effort. This is highlighted by Fig. 2 where we plot $S$ over $F$. Note, however, that we derived $S$ from $S=\alpha / F$ and thus while the graph is useful to visualize how variance of both variables is reduced from 5 to about 1 order of magnitude, it can not be used to predict $S$ or $\alpha$ from fecundity.

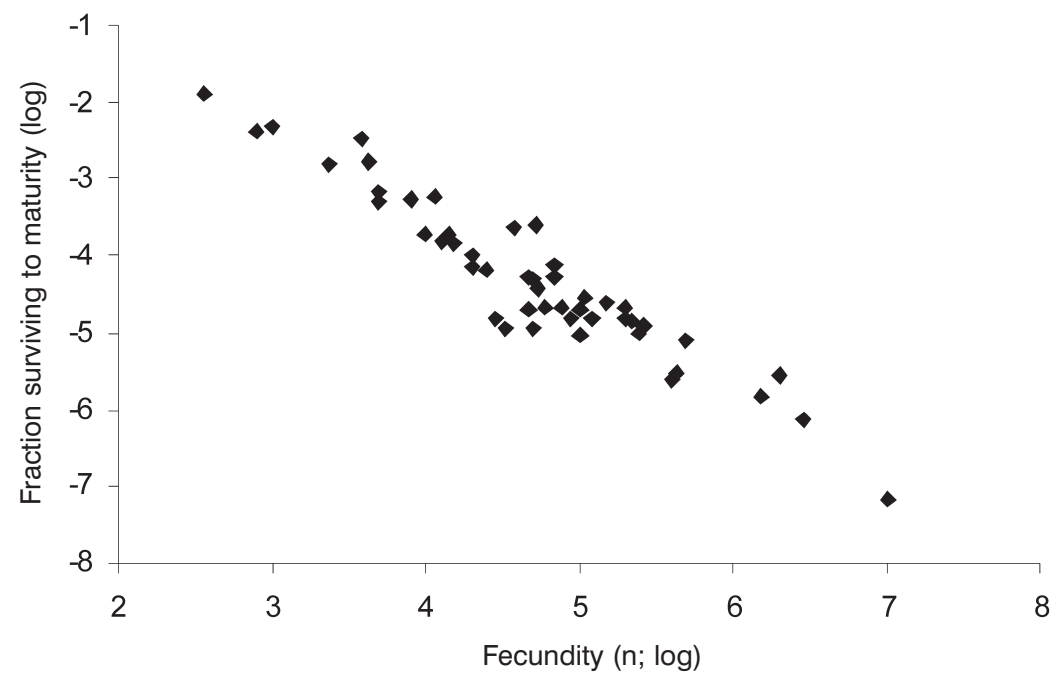

Fig. 2. Relationship between pre-adult survival $(S)$ and fecundity $(F)$ (note, however, that $S=\alpha / F$ and thus not independent of $F$ )

The lack of a relationship between fecundity and maximum annual reproductive rate should not be surprising given that the life-time reproductive rate at steady population sizes near the carrying capacity of the respective environment is unity, i.e. 
every spawner is replaced by one spawner, independent from fecundity and reproductive strategies.

\section{ACKNOWLEDGEMENTS}

We thank Daniel Pauly for his comments on the manuscript, and the quotes from early evolutionists, and Bernd Ueberschär for the ocean sunfish example in the Introduction. This study was in part supported by EU INCO Contract No. ICA4CT2002-50001.

\section{REFERENCES}

Anonymous, 2001. Report of the Working Group on the Assessment of Southern Shelf Demersal Stocks (WGSSDS), ICES Headquarters, 4-13 September 2001. ICES Council Meeting/ACFM: 05. http://www.ices.dk/reports/acfm/2001/wgssds/s1-2\%20Gen.Overview.pdf

Ballara S.L., Livingston M.E., 2001. Catches, size, and age structure of the 1998-99 hoki fishery. New Zealand Fisheries Assessment Report (Ministry of Fisheries) (6): 1-63.

Baranov F.I., 1918. [On the question of the biological basis of fisheries.] Izvestâ Otdela rybovodstva i naučno-promyslovyh issledovanii 1 (1): 81-128. (In Russian.)(Cited after Ricker 1975.)

Christiansen J.S., Fevolden S.E., Karamushlo O.V., Karamushko L.I., 1997. Reproductive traits of marine fish in relation to their mode of oviposition and zoogeographic distribution. ICES CM 1997/CC: 1-14.

Ciechomski J.D., Capezzani D.A., 1969. Fecundity of the Argentinean mackerel Scomber japonicus marplatensis. Marine Biology 2 (3): 277-282.

Cohen D.M., Inada T., Iwamoto T., Scialabba N., 1990. FAO species catalogue. Vol. 10. Gadiform fishes of the world (Order Gadiformes). An annotated and illustrated catalogue of cods, hakes, grenadiers and other gadiform fishes known to date. FAO Fisheries Synopsis.

Collette B.B., Nauen C.E., 1983. FAO species catalogue. Vol. 2. Scombrids of the world. An annotated and illustrated catalogue of tunas, mackerels, bonitos and related species known to date. FAO Fisheries Synopsis.

Collins L.A., Johnson A.G., Keim C.P., 1996. Spawning and annual fecundity of the red snapper (Lutjanus campechanus) from the northwestern Gulf of Mexico. pp. 174-188. In: Arreguín-Sanchez, F., Munro, J.L., Balgos, M.C., Pauly, D. (eds.) Biology, fisheries and culture of tropical groupers and snappers. ICLARM Conference Proceedings 48.

Deniel C., 1989. Modalités de l'ovogenèse et de la ponte, fécondité du chinchard Trachurus trachurus du golfe de Gascogne. Rapport final, IFREMER-UBO n 88.5.51.2003: 1-27.

Denney N.H., Jennings S., Reynolds J.D., 2002. Life-history correlates of maximum population growth rates in marine fishes. Proceedings of the Royal Society London 269: 2229-2237.

Ehrlich M.D., 1998. The early life history of the hake Merluccius hubbsi Marini, 1933 in the Argentine Sea for understanding its recruitment and population structure. $\mathrm{PhD}$ thesis, Universidad de Buenos Aires, Argentina. 
Fernandez I., Devaraj M., 1996. Dynamics of the Bombay duck (Harpodon nehereus) stock along the northwest coast of India. Indian Journal of Fishery 43 (1): 1-11.

Fletcher W.J., 1990. A synopsis of the biology and exploitation of the Australasian pilchard, Sardinops neopilchardus (Steindachner). Part I: Biology. Fisheries Department of Western Australia, Fisheries Research Report 88.

Foot T., 2000. Guinness Book of World Records 2001. Guinness World Records Ltd.

Froese R., Pauly D., (eds) 2000. FishBase 2000: concepts, design and data sources. ICLARM, Los Baños, Laguna, Philippines.

Gray C.L., 1990. Scup (Stenotomus chrysops): species profile. Rhode Island Department of Environmental Management, Division of Fisheries and Wildlife, Marine Fisheries Section.

Hart J.L., 1973. Pacific fishes of Canada. Fisheries Research Board of Canada Bulletin 180: $1-740$.

Hayes E., 1994. Snapper in New South Wales. NSW Fisheries Fishnote DF/37: 1-4.

Higham J.R., Nicholson W.R., 1964. Sexual maturation and spawning of the Atlantic menhaden. U.S. Fish and Wildlife Service, Fishery Bulletin 63 (2): 255-271.

Hjort J., 1914. Fluctuations in the great fisheries of northern Europe viewed in the light of biological research. Rapports et Proces-Verbaux des Reunions Conseil International pour l'Exploration de la Mer 20: 1-228.

Jessop B.M., 1993. Fecundity of anadromous alewives and blueback herring in New Brunswick and Nova Scotia. Transactions of the American Fisheries Society 122 (1): 85-98.

Junquera S., Román E., Paz X., Ramilo G., 1999. Changes in Greenland halibut growth, condition and fecundity in the Northwest Atlantic (Flemish Pass, Flemish Cap and southern Grand Bank). Journal of Northwest Atlantic Fisheries Science 25: 17-28.

Koli L., 1990. Suomen kalat. [Fishes of Finland.] Werner Söderström Osakeyhtiö, Helsinki. (In Finnish.)

Lamarck J.B.M., 1809. Philosophie Zoologique, ou exposition des Considérations relatives à l'histoire naturelle des Animaux; à la diversité de leur organisation et des facultés qu'ils en obtiennent. Dentu et l'Auteur, Paris.

Lewis R.M., Roithmayr C.M., 1981. Spawning and sexual maturity of Gulf menhaden, Brevoortia patronus. Fisheries Bulletin 78 (4): 947-951.

Longhurst A., 2002. Murphy's law revisited: longevity as a factor in recruitment to fish populations. Fisheries Research 56: 125-131.

MacGregor J.S., 1966. Fecundity of the Pacific hake, Merluccius productus (Ayres). California Fish and Game 52 (2): 11-116.

McPherson G.R., 1991. Reproductive biology of yellowfin tuna in the eastern Australian fishing zone, with special reference to the north-western Coral Sea. Australian Journal of Marine and Freshwater Research 42 (5): 465-477.

Melvin G.D., Dadswell M.J., Martin J.D., 1985. Impact of lowhead hydroelectric tidal power development on fisheries. 1. - A pre-operation study of the spawning population of American shad, Alosa sapidissima (Pisces: Clupeidae), in the Annapolis River, Nova Scotia, Canada. Canadian Technical Report on Fisheries and Aquatic Sciences (1340): 1-37.

Mertz G., Myers R.A., 1996. Influence of fecundity on recruitment variability of marine fish. Canadian Journal of Fisheries and Aquatic Sciences 53 (7): 1618-1625. 
Murphy M.D., Crabtree R.E., 2001. Changes in the age structure of nearshore adult red drum off West-Central Florida related to recruitment and fishing mortality. North American Journal of Fisheries Management 21 (3): 671-678.

Muus B.J., Dahlström P., 1974. Collins guide to the sea fishes of Britain and North-Western Europe. Collins, London, UK.

Muus B.J., Nielsen J.G., 1999. Sea fish. Scandinavian Fishing Year Book, Hedehusene, Denmark.

Myers R.A., 1997. Comment and reanalysis: paradigms for recruitment studies. Canadian Journal of Fisheries and Aquatic Sciences 54: 978-981.

Myers R.A., 2001. Stock and recruitment: generalizations about maximum reproductive rate, density dependence, and variability using meta-analytic approaches. ICES Journal of Marine Science 58 (5): 937-951.

Myers R.A., Barrowman N.J., 1996. Is fish recruitment related to spawner abundance. Fisheries Bulletin 94 (4): 707-724.

Myers R.A., Bowen K.G., Barrowman N.J., 1999. Maximum reproductive rate of fish at low population sizes. Canadian Journal of Fisheries and Aquatic Sciences 56: 2404-2419.

Myers R.A., Mertz G., 1997. Maximum population growth rates and recovery times for Atlantic cod, Gadus morhua. Fisheries Bulletin 95: 762-772.

Nakamura I., 1985. FAO species catalogue. Vol. 5. Billfishes of the world. An annotated and illustrated catalogue of marlins, sailfishes, spearfishes and swordfishes known to date. FAO Fisheries Synopsis.

Ricker W.E., 1975. Computation and interpretation of biological statistics of fish populations. Bulletin 191, Department of the Environment, Fisheries and Marine Service, Ottawa, Canada.

Sadovy Y., 2001. The threat of fishing to highly fecund fishes. Journal of Fish Biology 59 (Suppl. A): 90-108.

Sakamoto C.J., White D.A., 1974. A growth and fecundity study of Utah Lake walleye spawning on the Provo River, spring 1974. Proceedings of the Utah Academic Sciences and Arts Letter 51 (2): 69-72.

Scott W.B., Crossman E.J., 1973. Freshwater fishes of Canada. Bulletin of the Fisheries Research Board of Canada (184): 1-966.

Smith S.E., Au D.W., Show C., 1998. Intrinsic rebound potentials of 26 species of Pacific sharks. Marine and Freshwater Research 49 (7): 663-678.

Spillman C.-J., 1961. Faune de France: Poissons d'eau douce. Fédération Française des Sociétés Naturelles, Tome 65. Paris, France.

Spratte S., Hartmann U., 1997. Fischartenkataster: Süßwasserfische und Neunaugen in Schleswig-Holstein. Ministerium für ländliche Räume, Landwirtschaft, Ernährung und Tourismus, Kiel, Germany.

Stauffer R.C., (ed.) 1975. Charles Darwin's Natural selection: Being the second part of his big species book. Cambridge University Press, Cambridge.

Torstensen E., 1985. Fecundity of sprat from the Norwegian coast. ICES Council Meeting 1985/H: 56.

Tsimenidis N.C., 1980. Contribution to the study of the angler-fishes Lophius budegassa Spinola, 1807 and L. piscatorius L., 1758 in Greek seas. Institute of Oceanographic and Fisheries Research, Special Publication (4): 1-190. 
Walsh C., Middleton C., Davies N.M., 2003. Length and age composition of commercial snapper landings in SNA 1 and SNA 8, 2001-02. New Zealand Fisheries Assessment Report [Ministry of Fisheries] 2003 (12): 1-40.

Witherell D., 1996. Groundfish of the Bering Sea and Aleutian Islands area: a species profile. Pacific Fishery Management Council, Alaska.

Received: 16 May 2003 Accepted: 16 February 2004 